\title{
Current hepatitis A status in Canada
}

\author{
Jun Wu MD PhD, Shimian Zou MD PhD, Antonio Giulivi MD FRCPC
}

\begin{abstract}
J Wu, S Zou, A Giulivi. Current hepatitis A status in Canada. Can J Infect Dis 2001;12(6):341-344.
Hepatitis A, caused by the hepatitis A virus, occurs most frequently in developing countries, but also causes sporadic cases or outbreaks in industrialized countries. The most common route of transmission is fecal-oral. The incidence of hepatitis A varies with geography, and economic and environmental conditions. The epidemiological pattern of the disease has changed with improvements in hygiene and economic conditions. The incidence and prevalence of hepatitis A has decreased, while the average age of exposure and subsequent infection has increased. The present report describes the current status of hepatitis A in Canada. The incidence rate of reported cases in Canada varies from over 10/100,000 (1991) to 3.6/100,000 (1998), and is higher in males, 4.7/100,000 (1998), than in females, 2.5/100,000 (1998). The highest reported hepatitis A rates are in age groups 30 to 39 years and 40 to 59 years, and in British Columbia. Such information is important for assessing current immunization approaches and for decision-making about new preventive strategies against hepatitis A in Canada.
\end{abstract}

Key Words: Epidemiology; Hepatitis A; Hepatitis A virus; Viral hepatitis

\section{Statut actuel de I'hépatite A au Canada}

RÉSUMÉ : L'hépatite A, causée par le virus de l'hépatite A, est plus répandue dans les pays en voie de développement, mais elle cause aussi des cas sporadiques ou des épidémies dans les pays industrialisés. La voie de transmission la plus courante est la voie oro-fécale. L'incidence de l'hépatite A varie selon les régions et selon les conditions économiques et environnementales. Le tableau épidémiologique de la maladie a changé au fur et à mesure des améliorations apportées aux conditions d'hygiène et aux conditions économiques. L'incidence et la prévalence de l'hépatite $\mathrm{A}$ ont diminué, alors que l'âge moyen de l'exposition et de l'infection subséquente a augmenté. Le présent rapport décrit le statut de l'hépatite A au Canada. Le taux d'incidence des cas signalés au Canada varie de plus de 10/100 000 (1991) à 3,6/100 000 (1998) et il est plus élevé chez les hommes, 4,7/100 000 (1998) que chez les femmes 2,5/100 000 (1998). Les taux d'hépatite A les plus élevés signalés affectent les groupes de 30 à 39 ans et de 40 à 59 ans et la province de la Colombie-Britannique. Ce type de renseignements est important pour l'évaluation des approches d'immunisation actuelles et pour les prises de décision quant aux nouvelles stratégies de prévention de l'hépatite A au Canada.

$\mathrm{H}$ epatitis A is caused by hepatitis A virus (HAV), and is found worldwide, with a higher incidence and prevalence in developing countries than in industrialized countries. Only one serotype of HAV has been identified (1). Following exposure to $\mathrm{HAV}$, the incubation period is 15 to 50 days (mean 28 days) (2). Individuals are infectious during the late incubation period and the early stages of illness (3). Earlier human studies reported that viremia occurred only during the prodromal phase of illness. A recent study, however, has shown that HAV RNA was present in blood for an average of 95 days

Bloodborne Pathogens Division, Bureau of Infectious Diseases, Centre for Infectious Disease Prevention and Control, Health Canada, Ottawa, Ontario

Correspondence and reprints: Dr Shimian Zou, Bloodborne Pathogens Division, Bureau of Infectious Diseases, Centre for Infectious Disease Prevention and Control, Postal Locator 0601E2, Ottawa, Ontario K1A OL2. Telephone 613-946-8819, fax 613-952-6668,

e-mail shimianzou@hc-sc.gc.ca

Received for publication September 14, 2000. Accepted August 28, 2001 


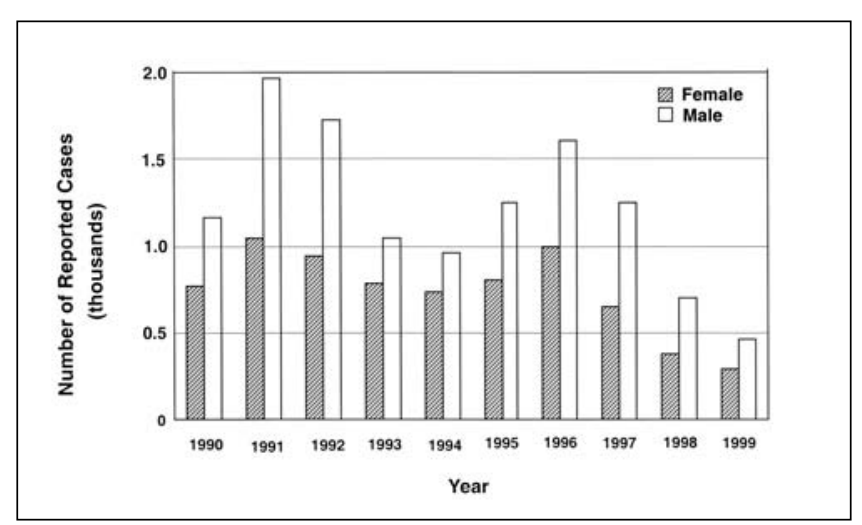

Figure 1) Annual nationally reported cases of hepatitis A in Canada from 1990 to 1999 (1999 numbers are preliminary)

during human HAV infection and viremia persisted after the onset of symptoms (average 79 days) (4). These findings suggest that the infectious period may be longer than previously described. Hepatitis A has no chronic carrier state, and infection is believed to result in lifelong immunity (3).

Acute hepatitis A is clinically indistinguishable from other types of viral hepatitis. The symptoms include influenzalike symptoms, such as fever, chills and a general feeling of weakness, as well as anorexia, nausea, malaise, fatigue, abdominal pain, fever, jaundice, dark urine and light-coloured stools. Recovery usually requires four to six weeks. Acute hepatitis A is normally diagnosed by detecting HAV immunoglobulin $[\mathrm{Ig}] \mathrm{M}$ and increased levels of serum transaminase. The HAV-IgM level peaks during the acute or early convalescent phase, and declines over three to four months (5), but HAV-IgM may remain for one to two years. HAV-IgG reaches a peak level in the convalescent phase and remains (5). Administration of HAV vaccine results in an IgM response in approximately $5 \%$ of cases (D Scheifele, personal communication). Therefore, while HAV-IgM generally indicates a recent infection (6), a positive HAV-IgM test result must be interpreted in the context of the specific patient.

Hepatitis A is mainly transmitted by the fecal-oral route, either through interpersonal contact or ingestion of contaminated food or water. People with risk factors associated with a higher incidence of hepatitis A include intravenous drug users and homosexual men, as well as those living in an area lacking adequate sanitation and in some correctional facilities.

To date, there is no effective treatment for hepatitis A. The most important prevention measure is interrupting fecal-oral HAV transmission by promoting good personal hygiene, proper food handling practices, and clean drinking water and proper sanitary facilities. Other prevention measures include active immunization with hepatitis A vaccines and passive immunization with Ig pre or postexposure. Immunization programs have been proven to be cost effective in the prevention of hepatitis A. It is important that immunization strategies are adapted to the current epidemiological pattern of hepatitis A. The present report provides current epidemiological information on hepatitis A in Canada.

\section{DATA AND METHODS}

Hepatitis A is reportable in all Canadian jurisdictions. National hepatitis A reports were obtained from the Division of Disease Surveillance, Bureau of Infectious Diseases, Centre for Infectious Disease Prevention and Control, Health Canada. Data were collected by provinces and territories, and sent to Health Canada for compilation and removal of duplicates. Hepatitis A cases per year since 1990 were analyzed, and distributions of the disease among different population groups and jurisdictions are described.

\section{RESULTS AND DISCUSSION}

Temporal trends of hepatitis A: Hepatitis A occurs as both endemic and epidemic cases. In high endemic areas, the incidence of acute hepatitis A in adults is relatively low because of prior exposure to HAV in childhood. In low endemic areas, the incidence of HAV infection among young children is low, so the proportion of susceptible individuals, especially young adults, is high. Hepatitis A occurs in cyclical epidemics approximately every 10 years (7).

Figure 1 shows the total number of reported cases of acute hepatitis A in Canada in each year from 1990 to 1999. There are more reported cases in males. The peak rates in 1996 likely reflect the outbreaks in Quebec (280 cases/100,000 population) (8) and Ontario (420 cases/100,000 population) (9). In addition, the peak seen in 1991 and 1992 could be attributed to the clusters of cases that occurred in those two years in Montreal and Toronto $(10,11)$. From January to midNovember 1991, 389 cases of hepatitis A were reported in metropolitan Montreal, representing a fourfold increase in incidence rate compared with the rate from 1984 to 1989. From January to September 1991, 274 cases of hepatitis A were reported to the City of Toronto Department of Public Health, also a fourfold increase over the number of cases reported during the same period in 1990. With the exception of these outbreaks, the rate of acute hepatitis A cases appears to decline from 1990 to 1999.

The reported cases of acute hepatitis A considerably underestimate the true incidence of HAV infections due to underreporting and the high frequency of subclinical infections in children. The frequency of HAV infection may also be estimated by the detection of IgM anti-HAV antibody in serum. In the United States, hepatitis A is one of the most frequently reported infectious diseases and accounts for as much as $65 \%$ of all viral hepatitis cases each year. It has been estimated that approximately 150,000 people become infected with HAV each year in the United States. The highest incidence is in children, with nearly $30 \%$ of the reported cases in children younger than age 15 years (7).

Age and sex distribution of hepatitis A: The epidemiology of hepatitis A in Canada is changing. As living standards improve, the incidence and prevalence decline, but the average age of persons with acute hepatitis A increases. Similar epidemiological changes have been seen in many countries worldwide $(12,13)$. These changes have an impact on mor- 


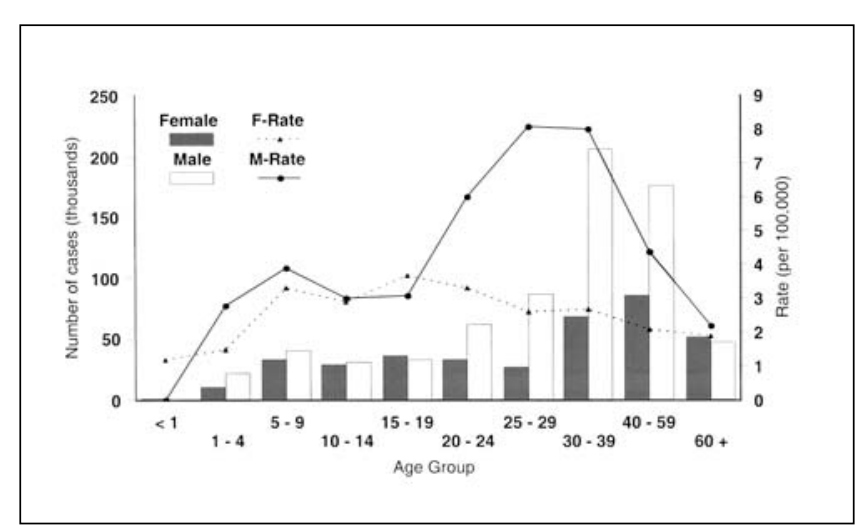

Figure 2) Numbers and rates of nationally reported hepatitis $A$ cases in Canada by sex and age group in 1998. F-Rate Female rate; $M$-Rate Male rate

bidity because the severity of symptoms increases with the age of the infected individual. Thus, as natural immunity in the population decreases, particularly in children and young adults, the number of susceptible individuals increases, enhancing the likelihood of HAV outbreaks.

Figure 2 shows the reported hepatitis A rates for different age groups. The rates are higher for males than for females, except in the five- to 19-year age group. In the 20- to 59-year age group, this sex difference was significant. In the 25- to 29-year and 30- to 39-year age groups, hepatitis A incidence in males was approximately three times that of the incidence in females. However, there is no evidence that males are more susceptible to HAV than females (14). The differences in the hepatitis A incidence rate between males and females may be related to risk activities. Other studies also confirm that seropositivity is lowest in the 20- to 29 -year age group and increases to approximately $60 \%$ by the age of 50 years. The greatest increase in HAV seropositivity was from $25 \%$ to $46 \%$ between the 20- to 29- and 30- to 39-year age groups (15). Variation among provinces and territories: The rates of reported hepatitis A cases in Canada are significantly different across the provinces and territories. The highest rates are observed in British Columbia and the lowest rates in the Atlantic provinces (Figure 3). The regional and sex differences suggest that further investigation of risk factors and immunization strategies within higher risk groups are necessary. Travel overseas, especially to hepatitis A endemic areas, and contact with travellers are risks for a large portion of reported cases in some regions. The risk for susceptible travellers in endemic areas has been estimated at three to five/1000 persons/month (15). It is already recommended that this group receive the HAV vaccine before travelling. Although screening for HAV antibodies is useful for eliminating unnecessary vaccinations for adult travellers, it is impractical because the cost of serological testing generally exceeds that of immunization and serological testing is not readily available in some areas $(16,17)$. There is no current Canadian recommendation as to whether to screen for IgG anti-HAV antibody before administration of vaccine or Ig.

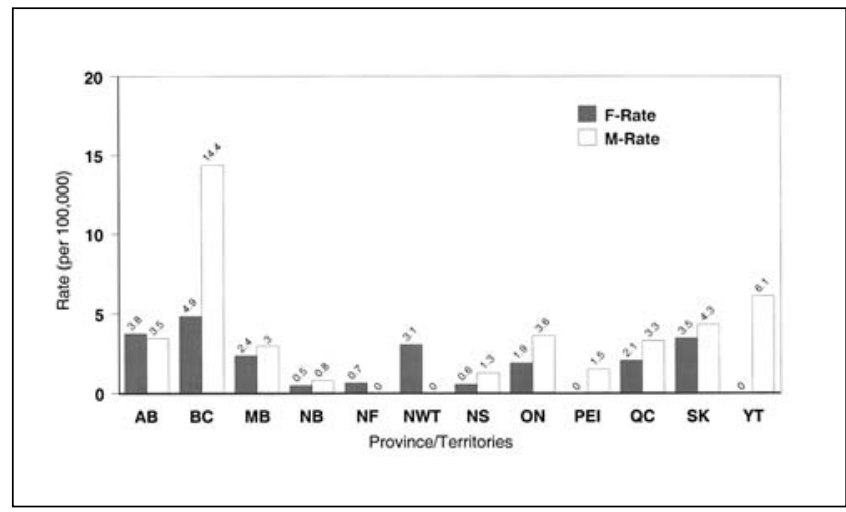

Figure 3) Rates of nationally reported hepatitis A cases in Canada by province or territory in 1998. AB Alberta; BC British Columbia; F-Rate Female rate; MB Manitoba; M-Rate Male rate; NB New Brunswick; NF Newfoundland; NS Nova Scotia; NWT North-West Territories; ON Ontario; PEI Prince Edward Island; QC Quebec; SK Saskatchewan; YT Yukon Territory

Implications for hepatitis A vaccination policy in Canada: Improvement in sanitation has had a paradoxical impact on hepatitis A status in the population because an increasing number of susceptible adults creates the potential for epidemics. Thus, effective prevention of HAV infection has become increasingly important. Currently, hepatitis A vaccine is not routinely recommended as part of childhood immunization programs in Canada. The vaccine is given to individuals in groups at increased risk for HAV infection (18).

Routine immunization against HAV is recommended for children in 11 states in the United States. In February 1999, the Centre for Disease Control and Prevention's Advisory Committee on Immunization Practices recommended that children living in areas with consistently increased hepatitis A incidence should receive routine vaccination. These are areas where the average annual rate of hepatitis A incidence during the period between 1987 and 1997 was greater than $20 / 100,000$ population or approximately twice the national average $(19,20)$. As the epidemiology of hepatitis A shifts, it is worthwhile to reassess current immunization strategies in Canada. This includes determing the cost effectiveness of different strategies. Continuing targeted studies and surveillance are needed to develop evidence for ongoing decision-making.

The annual direct and indirect costs of treating patients and controlling outbreaks of hepatitis A in the United States are estimated to be US $\$ 200$ million. Additional economic costs are incurred as adults with hepatitis A miss an average of 27 days of work, which is approximately US $\$ 2,600$ in lost wages for each adult case. For 150,000 cases, this translates into US $\$ 390$ million in lost wages every year. These estimates do not include business losses related to outbreaks of the disease incurred by restaurant and tourism industries.

cost effectiveness data provide important information for evaluating strategies for hepatitis A prevention. The decision to adopt a new vaccination program against HAV should be based on the epidemiology of the disease and the cost effec- 
tiveness of the program in a population. A current study, initiated and funded by Health Canada, is being undertaken by an expert group to analyze the cost effectiveness of different immunization programs directed against HAV infection in Canada. Universal immunization against hepatitis $B$ has been a success in Canada. Because the infrastructure for hepatitis $B$ immunization is already in place and the combined hepatitis A and B vaccine is now available, the cost of a universal immunization program against HAV would be low if this program is implemented together with the hepatitis B vaccination program. Results from the current cost effectiveness analysis should aid the decision-making process with respect to whether to recommend such a combined vaccination program.

ACKNOWLEDGEMENTS: The authors thank Drs B Hogg, M Krahn, $\mathrm{R}$ Remis and $M$ Sherman for their input into this article. Data are from the Division of Disease Surveillance, Health Canada, Ottawa, Ontario.

\section{REFERENCES}

1. Margolis HS, Alter MJ, Hadler SC. Viral hepatitis. In: Evans AS, Kaslow R, eds. Viral Infections of Humans: Epidemiology and Control, 4th edn. New Haven: Plenum Publishing, 1997:363-418.

2. Provost PJ, Wolanski BS, Miller WJ, Ittensohn OL, McAleer WJ, Hilleman MR. Physical, chemical and morphologic dimensions of human hepatitis A virus strain CR326 (38578). Proc Soc Exp Biol Med 1975;148:532-9.

3. Hadler SC. Global impact of hepatitis A virus infection. In: Hollinger FB, Lemon SM, Margolis H, eds. Viral Hepatitis and Liver Disease: Proceedings of the 1990 International Symposium on Viral Hepatitis and Liver Disease. Baltimore: Williams \& Wilkins, 1991:14-20.

4. Bower WA, Nainan OV, Han X, Margolis HS. Duration of viremia in hepatitis A virus infection. J Infect Dis 2000;182:12-7.

5. Koff RS. Clinical manifestations and diagnosis of hepatitis A virus infection. Vaccine 1992;10(Suppl 1):S15-7.

6. National Advisory Committee on Immunization (NACI). Statement on the prevention of hepatitis A infections. Can Commun Dis Rep 1994;20:133-43.
7. Shapiro CN, Coleman PJ, McQuillan GM, Alter MJ, Margolis HS. Epidemiology of hepatitis A: seroepidemiology and risk groups in the USA. Vaccine 1992;10(Suppl 1):S59-62.

8. Fortin A, Milord F. Hepatitis A in restaurant clientele and staff - Quebec. Can Commun Dis Rep 1998;24:53-9.

9. Hockin J, Isaacs S, Kittle D, Brimmer G, Bailey N, Tamblyn S. Hepatitis A outbreak in a socially-contained religious community in rural southern Ontario. Can Commun Dis Rep 1997;23:161-6.

10. Allard R, Douise L, Guy M, Deshaies D. Hepatitis A in downtown Montreal, Quebec, 1990-1992. Can Commun Dis Rep 1992;21:71-5.

11. Hepatitis A among homosexual men - United States, Canada, and Australia. MMWR Morb Mortal Wkly Rep 1992;41:155,161-4.

12. Sawayama Y, Hayashi J, Ariyama I, et al. A ten year serological survey of hepatitis A, B and C viruses infections in Nepal. J Epidemiol 1999;9:350-4.

13. Beran J, Douda P, Rychly R. Seroprevalence of viral hepatitis A in the Czech Republic. Eur J Epidemiol 1999;15:805-8.

14. Barros H, Oliveira F, Miranda H. A survey on hepatitis A in Portuguese children and adolescents. J Viral Hepat 1999;6:249-53.

15. Kocuipchyk FR, Lightfoot PJ, Stout I, Devine RD. Seroprevalence of hepatitis A antibodies in travellers at the Edmonton Travellers' Health Clinic - Alberta. Can Commun Dis Rep 1995;21:65-71.

16. Parry JV, Farrington CP, Perry KR, Waight PA, Mortimer PP, Miller E. Rational programme for screening travellers for antibodies to hepatitis A virus. Lancet 1988;i:1447-9.

17. Tormans G, Van Damme P, Van Doorslaer E. Cost-effectiveness analysis of hepatitis A prevention in travellers. Vaccine 1992;10(Suppl 1):S88-92.

18. Supplementary statement on hepatitis A vaccine (ACS-4). An Advisory Committee Statement (ACS). National Advisory Committee on Immunization (NACI). Can Commun Dis Rep 2000;26:12-8.

19. Prevention of hepatitis A through active or passive immunization: Recommendations of the Advisory Committee on Immunization Practices (ACIP). MMWR Morb Mortal Wkly Rep 1999;48(RR-12):1-37.

20. Prevention of hepatitis A through active or passive immunization: Recommendations of the Advisory Committee on Immunization Practices (ACIP). MMWR Morb Mortal Wkly Rep 1996;45(RR-15):1-30. 


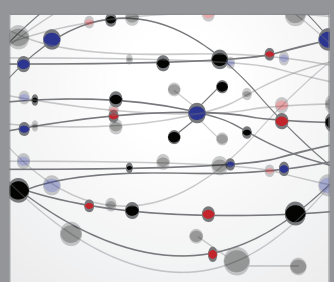

The Scientific World Journal
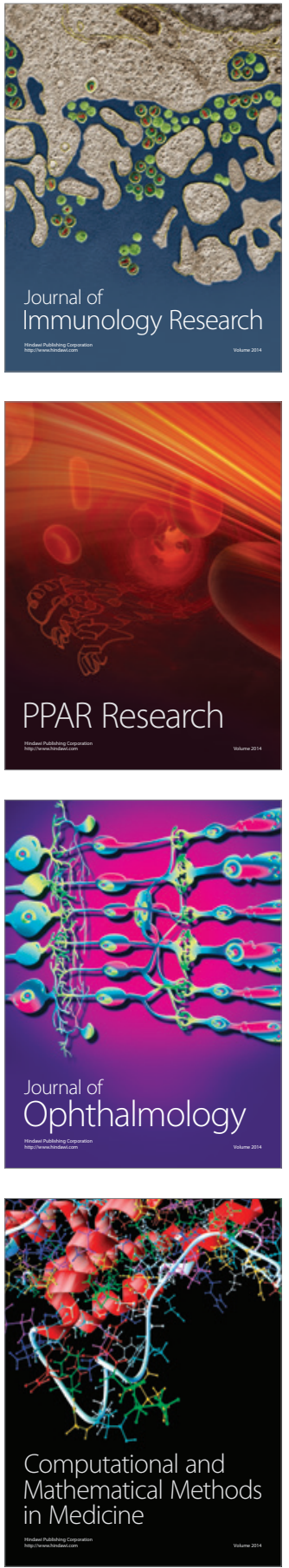

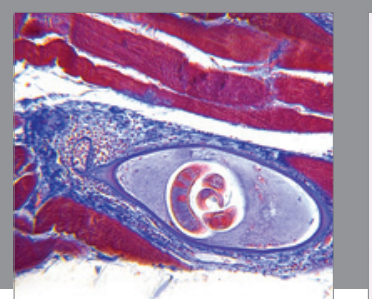

Gastroenterology Research and Practice

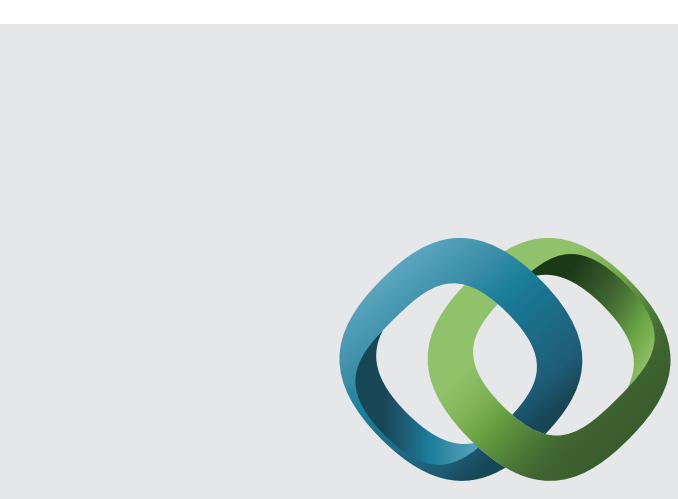

\section{Hindawi}

Submit your manuscripts at

http://www.hindawi.com
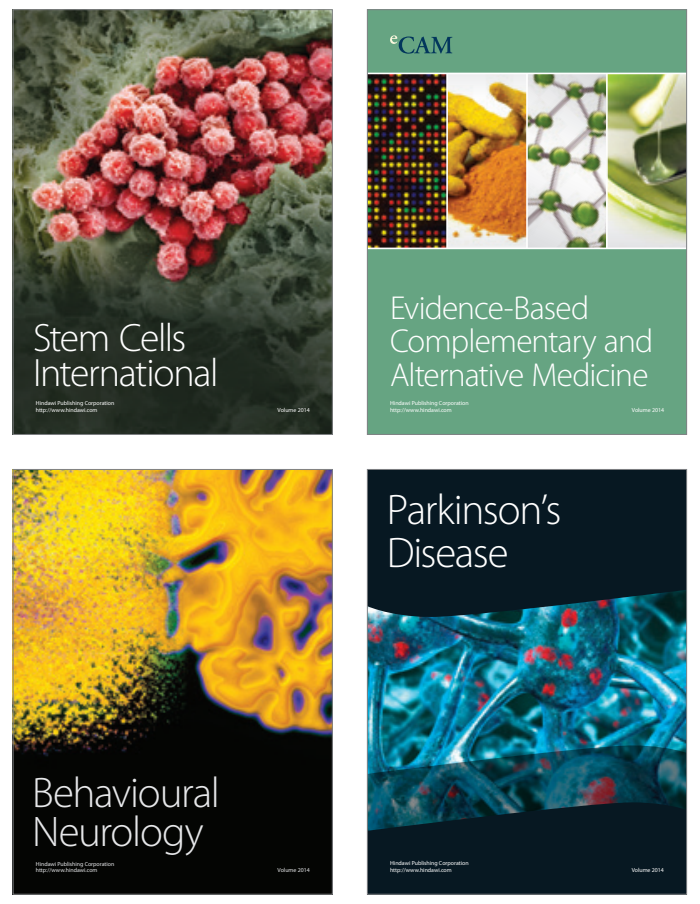
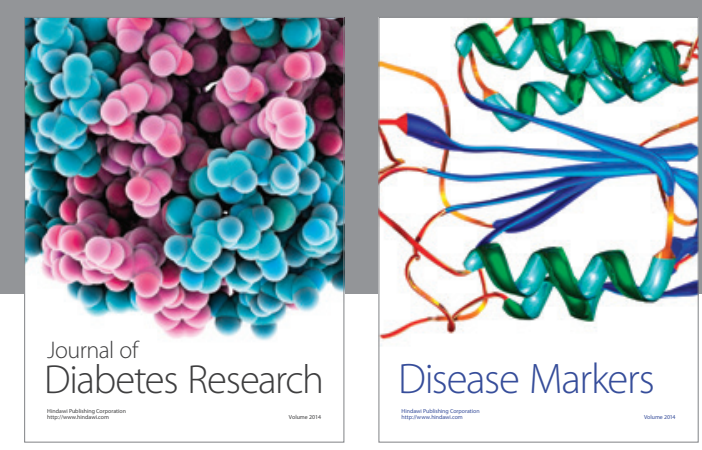

Disease Markers
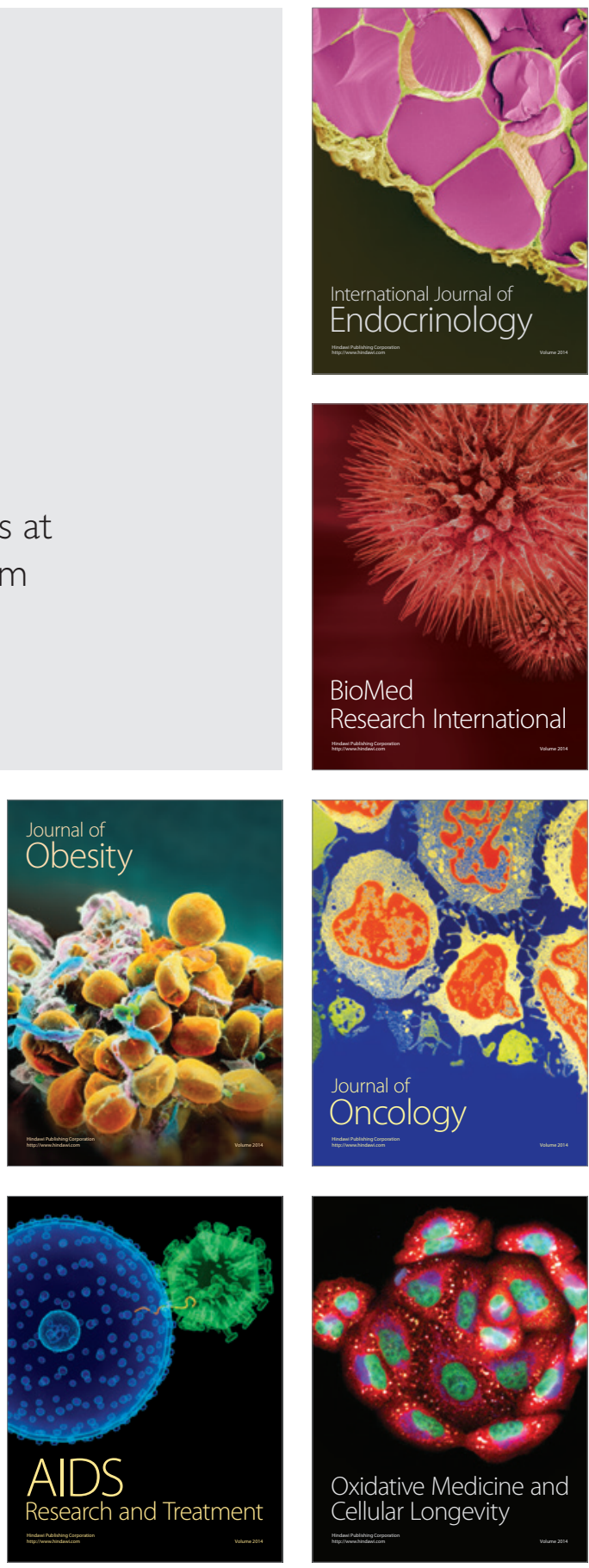